\title{
Correction: Optimizing endovascular stroke treatment: removing the microcatheter before clot retrieval with stent-retrievers increases aspiration flow
}

Nikoubashman O, Alt JP, Nikoubashman A, et al. Optimizing endovascular stroke treatment: removing the microcatheter before clot retrieval with stent-retrievers increases aspiration flow. J Neurointerv Surg 2017;9:459-462.

In this article the contributor statement should have read 'conception and design: all authors. Acquisition of data: all authors. Analysis and interpretation of data: all authors. Original draft of the article: JPA. Critically revising the article: all authors.

(C) Article author(s) (or their employer(s) unless otherwise stated in the text of the article) 2018. All rights reserved. No commercial use is permitted unless otherwise expressly granted.

J Neurolntervent Surg 2018;10:e10. doi:10.1136/neurintsurg-2016-012319corr1

A) Check for updates 